\title{
Research on the Information Management for College Social Security
}

\author{
Shufeng $\mathrm{Ni}$ \\ Jilin Agricultural University \\ 512375850@qq.com
}

Keywords: College; Social security; Information management

\begin{abstract}
Information is an important sign of modern economical development and college social security information management also needs it. This paper will analyze problems that might occur in college social security management as well as the necessity to carry out information management, and will also suggest effective measures to improve the information management for college social security.
\end{abstract}

\section{Introduction}

In order to make the social security system in China popular and continual, China has issued a series of laws and regulations. The college social security is beneficial to implement the talent strategy and keep a steady and quick development pace for colleges, which can also guarantee immediate interests of all faculties. Concerning this, we should fully be aware of the importance of social security management, positively face the challenges college social security management may bring about, and try tireless efforts to implement college social security information management.

\section{Present Working Condition of College Social Security Management}

The Management Becomes more Difficult with more People. At present, there are more and more complements in government offices joining in social security. While facing the fact that there are skying rocketing information of them, and accumulated securities types, problems occur to the college social security. Traditional office ware such as excel cannot satisfy daily management requirement and the quantity as well as the operation frequency both affect the management efficiency, so we cannot guarantee to correctly deal with the information.

Big Risk of Data Information Safety. Social security often has some personal information and privacy, if we adopt traditional management we may disclosure the information during the operation process. What's more, there might be duplicated data and data miss and all those will bring about data information safety risk.

Data Checking and Statistics. Personal information and sorts of social security information collection are included in college social security management and if the management cannot be convenient and satisfy the needs directly, it will trigger effect on the efficiency of social security management. In the management of social security, we have to update the data, information collection at different times and security payment check etc. and we cannot guarantee the management efficiency and accuracy of data.

\section{Existing Problems in College Social Security Information Management}

The Matching Relation between Social Security Integrated Management and Resource Database Construction. Information database, including micro information data for relevant business is generated at the front level of social security, however, the construction site of social security resource database and how to construct are problems people have been arguing with and paid attention to for a long time, If the resource database is scattered, certain management cost and equipment cost should be input; and single database construction cannot keep a guarantee technically.

At present, more and more people participate in the social security, which will bring pressure for 
the database maintaining. Concerning this, we should research on the capacity and performance of current equipment and at the same time strengthen the investment on equipment and maintaining. While updating the resource database, we have to guarantee the necessity and feasibility in case of information delay and inconsistency so as to carry out unified management. In addition, we have to adopt measures to guarantee the data safety and decrease the cost of managing and maintaining the information. Moreover, we should also adopt relevant technology to analyze the social security data so as to support making better decisions and lay a foundation for integrated management. With the development of information technology, the cost for renting communication lines is decreasing and its bandwidth, reliability and real-time capability improves.

The Integration of Social Security Card and Identification Card. In recent years, China has issued a lot of new-edition social security card to replace identification card with unified copy and the observe side shows Social security card for People's republic of China while the reverse side shows holder's name, social security number, issue unit and photo. Social security card is an electronic certificate showing that people can enjoy certain tights which can check information and deal with certain business. Moreover, it can be used to accomplish paying social security fees and medical fees, picking supporting compensations etc. The card integrated identification card and social security card information has comprehensive functions but whether we should use social security card to replace identification card should be a problem.

We should pay attention to the above problem in the process of carrying out social security information management. In reality, the new social security card and second-generation identification card has the same integrated circuit card, which can be used to encrypt and is safe. It can be used to fully protect sensitive data. The second-generation identification card is equipped with Fingerprint Authentication and biometric information identity technology so as to provide further guarantee. Therefore, identification card and social security card can be integrated technically.

To being with, the integration of identification card and social security card can save cost. No matter the 2-nd generation card or social security card can help to guarantee the information safety and accuracy. So, advanced technology should be equipped with, which needs cost. The integration of them will help to save lots of social resources as well as cost in terms of operation and management.

Secondly, the integration is beneficial to the construction of college human resource database. The social security data needs regular fixed information comparison so as to carry out information correction and confirmation. The integration is also helpful to combine the identification information as well as the social security information, which will be conducive to the basic frame construction of college information database, decrease the regular information change and guarantee timely information processing as well as effectiveness. What's more, the integration will be helpful to prove the identification of the holder and decrease the criminal behaviors.

The Relation between Social Security Information System and College Information Database Construction. It is necessary to establish unified and perfect college information database because it is beneficial to information resource integration, develop and adopt the information resource. Based on the college information database construction, we can provide help to the national information database construction, which is beneficial to the information sharing among various departments of colleges.

The construction of information database cannot only record the social security information but also have a better understanding of statistics information, which is beneficial to information sharing and better management.

At present, the college information database construction is not perfect enough and the location, member information change of people who participate in social security cannot be changed in time, which is not conducive to the construction of college information database and will affect the college information resource management. In addition, the recent information cannot be timely responded. Concerning this, we should take certain measures to encourage them to update their information and contribute to the college information database construction. 
Apply New Technology and Improve the Quality of Social Security Service. Information technology management is the main development direction of college social security work and the adoption of information technology can guarantee the service quality and working efficiency.

Electronic affair construction of social security can help to satisfy the needs of security personnel. In addition, the construction of internet virtual service center will enable them to operate in different places and at different time so as to enjoy real-time service. Moreover, those who have been retired and are not healthy enough can take advantage of telephone network to deal with related service.

Information application will bring about intellectual development, in decision making system, the social security information center has a glittering array of data, which will come up with suggestions quickly while taking advantage of some software. Moreover, it will provide convenience for the electronic business management level to better satisfy the requirement of more services.

The network system and effective information will help to better realize electronic business. Some design ideas and software tool can provide long term and short time suggestions, which will help to deal with the information management system and other docking problems. To conclude, it is conducive to the upgrading of both software and hardware as well as the data transmission.

\section{The Importance of College Social Security Information Management}

Improve Social Security Management Efficiency. The application of information management in college social security management will help to modify, report, do statistics and check data and decrease the working time. At the same time of improving the management working efficiency, it can also help to improve the accuracy of data and fully guarantee the modernized development of college social security management.

Regulate the Social Security Management Procedure. The college social security management is being reformed and perfected. During the process, the business procedure of social security management also changed along with the change of social security policy. Based on the application of information management, managers can timely master the business procedure and strictly work according to the rules and regulations. Managers can help to optimize the procedure to full guarantee the management service quality and avoid mistakes so as to make a better development.

Perfect the College Human Resource Management System Information. We have to fully understand the key role colleges play in management system, which will help to provide managers enough information and let them work more efficiently.The information management of college social security is beneficial to the construction of information management system and is able to provide reliable data support. Moreover, it will also guarantee the information accuracy, integrity and resource sharing.

Provide Reliable Information Data for Policy-based Decision. College management work is policy-based and transactional. As a part of college human resource work, the social security management can guarantee the data quality based on information application, which is able to reasonably summarize and analyze various data. Based on this, we can have some rules which will help human resource managers to make correct policy-based decisions.

\section{Measures for College Social Security Information Management}

Clear the Importance of Information Construction and Make Promotions. College managers should take more advantage of college websites and journal so as to better construct the information management for college social security. What's more, during the promotion, we have to timely deal with issues and let college managers to fully understand its importance and let the public know better about the work so as to facilitate the smooth development.

Combine the Development Condition and Do Better Service. The construction of information management system is the main body of college social security. Concerning this, we should carry 
out relevant development based on the current condition and requirement. During the process of running the information management, we should timely perfect and advance the system based on the development and management of colleges so as to provide better service.

Pay Attention to the Information Safety Construction and Do Supervision. As an important part of the social security construction, we should strengthen the safety construction of the system so as to guarantee the smooth operation of management system, which asks us to do the construction and maintenance for the hardware and software system. In addition, we should timely operate the upgrading of software, update the firewall, prevent the loss of important messages and strengthen the safety of data.

Strengthen Various Information Exchanging, Do Information Sharing. In the process of carrying out information management for college social security, we ahem to strictly regulate the information data processing procedure so as to guarantee the data accuracy and timely organize the data in order to timely deal with and delete duplicated and useless data. While keeping the accuracy and authenticity of data, we should also strengthen information sharing and exchanging so as to make quicker operation, which will be helpful to the steady development.

\section{Conclusion}

The information management of college social security has a long way to go. During the management process, managers should strengthen their awareness in various aspects. At the same time, we should also combine the current development situation of college so as to come up with proper measures and make faculties to do contributions to the colleges.

\section{References}

[1] Yang Yuemei. Reflection on the Current Pension system reform for government institutions [J] .Economist2016,(2):91-92

[2] Liu Xiaoyan. Study on the information management of college human resource [J]. China Information Times,2011,(5):50-52

[3] Sun Liyan.Study on the basic human resource and information construction of social security [J] . China Management Informationization 2015,(8):62

[4] Hu Zhihong. Problems and countermeasures for the information construction of social security [J] .Public forum ( Journal of Shandong Institute of Trade Unions' Amministration Cadres )

[5] Hu Xiaoyi. Take all-purpose card to fully push the information construction for human resource social security- A talk on China's human resources and social security information meeting [EB/OL].[2011-06-16]. 